\title{
The Effects of Social Exchange Perspective on Employee Creativity: A Multilevel Investigation
}

\author{
Li-Yueh Lee \\ Kun Shan University, Tainan City, Taiwan
}

\author{
Sou Veasna \\ Asia Euro University, Phnom Penh, Cambodia
}

\begin{abstract}
Procedural justice and POS (perceived organizational support) are two of the most important rational social exchange mechanisms. This study examined their roles on employee-supervisor pair relationships at specific work units in R\&D. Data were obtained from a survey of employee-supervisor dyadic design of 78 high-tech firms located in a major city in southern Taiwan. At the cross-level analysis, the results of HLM (hierarchical linear modeling) indicated that both procedural justice and POS have significant influence on individual outcomes such as job engagement, satisfaction, and creativity. At the individual-level analysis, the results of SEM (structural equation modeling) provided support for all proposed hypotheses. The extension of the study findings related to the conceptual and practical issues of social exchange were discussed.
\end{abstract}

Keywords: POS (perceived organizational support), procedural justice, employee engagement, job satisfaction, employee creativity

\section{Introduction}

When employees are satisfied and deeply engaged in jobs, they may refer to their organizations treat them fairly and perceive higher levels of support. This phenomenon can be referred to the social exchange or organizational justice theories. Social exchange theory has provided very clear conceptual lens with regard to employment relationship (Rhoades \& Eisenberger, 2002; Skarlicki \& Latham, 2005). Social exchange theory explains the formation and maintenance of interpersonal relationship between two parties (i.e., employees and employers) in terms of the reciprocation procedures (Blau, 1964; Chen, Aryee, \& Lee, 2005). It is more likely to signal to increase employees' beliefs and organization values (Tremblay, Cloutier, Simard, Chênevert, \& Vandenberghe, 2010). A major social exchange perspective in an organizational behavior refers to POS (perceived organizational support) (Bies, 2005; Chen et al., 2005).

At individual-level analysis, organizational researchers have proposed that employees with higher levels of POS will result in higher levels of job satisfaction (e.g., Baranik, Roling, \& Eby, 2010; Erdogan \& Enders, 2007; Taris \& Schreurs, 2009), organizational commitment (e.g., Baranik et al., 2010; Casper, Harris, Taylor-Bianco, \& Wayne, 2011; Tremblay et al., 2010), and decrease employee's intention to quit (Zhang, Farh, \& Wang, 2011). However, cross-level investigations have been very rare, we thus proposed POS as one of key independent factors to predict employee's job engagement, satisfaction, and creativity, using cross-level analysis.

Furthermore, organizational justice has been regarded as another important factor for employee 
engagement, satisfaction, and creativity. Previous studies have identified four dimensions of organizational justices: procedural justice, distributive justice, informational justice, and interpersonal justice. As suggested by Holtz and Harold (2009), and Loi, Yang, and Diefendorff (2009), organizational justice has been classified into two levels of analyses: distributive and procedural justice at organization-focused or the between-person level (group-level), and interpersonal and informational justice at supervisor-focused or the within-person level (individual-level), respectively. Interestingly, George and Jones (2008) recognizes procedural justice as one of the most key factors of organizational justice. Therefore, procedural justice is proposed to examining the influences on individual outcomes, such as employee engagement, job satisfaction, and employee creativity at cross-sectional studies on high-tech industries.

Since previous studies have tested four sub-dimensions of organizational justice as single field studies at different situations, such as national health insurance (Scott, Colquitt, \& Zapata-Phelan, 2007), and the Chinese steel state-owned enterprise (Begley, Lee, \& Hui, 2006) and cross-sectional companies (Ambrose \& Schminke, 2009), university faculty (Judge \& Colquitt, 2004), and acquisition companies (Klendauer \& Deller, 2009), they failed to classify and test these sub-dimensions as individual level or organizational level analyses. Therefore, multilevel validation about organizational justice deserves further validation.

Research on POS (Eisenberger, Huntington, \& Sowa, 1986; Lio, Hang-yue, \& Foley, 2006) and procedural justice (Colquitt \& Greenberg, 2003; Judge \& Colquitt, 2004) have demonstrated the fairness can affect attitudes and behaviors of employees, as well as organizational outcomes. Based on these rationales, this study intends to integrate social exchange theory, organizational justice theory, and relevant creativity theory to understand how POS and procedural justice influence employee individual outcomes at the cross-level analysis. This study also aims to identify the effects of employee engagement in job satisfaction and employee creativity at work.

\section{Theoretical and Hypotheses Development}

\section{The Effects of Procedural Justice}

According Greenberg (1993) and Lambert, Hogan, and Griffin (2007), all types of justice (i.e., procedural, distributive, informational, and interpersonal) play an important role on individuals' organizational attitudes. However, at some level, procedural justice and interactional justice grew in prominence. Procedural justice focuses on fair distribution of outcomes across employees to encourage high levels of work motivation (George \& Jones, 2008; Greenberg, 1993). Justice theories suggest that when an organization is deemed as fair, employees will be more likely to make an effort to improve their work (Moon, Kamdar, Mayer, \& Takeuchi, 2008). According to Loi et al. (2009) and Holtz and Harold (2009), procedural justice has been classified as between-person level (group-level) or organization-focused. Thus, procedural justice at organizational level is emphasized in this study. Procedural justice refers to the perceived fairness of the procedures used to make decisions about the distribution of outcomes (Colquitt, Conlon, Wesson, Porter, \& Yee-Ng, 2001; George \& Jones, 2008).

Most of recent studies use procedural justice to predict employee's trust behavior in organization (e.g., Aryee, Budhwar, \& Chen, 2002; Tremblay et al., 2010), and OCB (organizational citizenship behavior), affective commitment, and turnover intention (Paré \& Tremblay, 2007). However, the link between procedural justice and employee's job engagement is very rare, especially in a cross-level study. While at individual level analysis and self-report scale, this relationship has been uncovered at unspecific and cross-samples studies (e.g., Saks, 2006; Sze \& Angeline, 2011). Following social exchange theory and procedural justice suggest that when organizational decision-making is consistent and meets the bias suppression rule (Ang, Van Dyne, \& Begley, 
2003), employees have positive assessments of procedural justice (Cohen \& Veled-Hecht, 2010; George \& Jones, 2008). In addition, the job engagement model suggests that when employees have high perceptions of justice in their organization, they are more likely to feel obliged to perform greater levels of engagement (Maslach, Schaufeli, \& Leiter, 2001). Based on this rationale, the following hypothesis is proposed.

H1: There is a positive cross-level relationship between procedural justice and job engagement.

McFarlin and Sweeney (1992), and Alexander and Ruderman (1987) indicated that procedural justice accounted for job satisfaction. Organizational justice research indicates that procedural justice is positively related to job satisfaction (e.g., Saks, 2006), and expatriate outcomes in Chinese hotel industry (Hon \& Lu, 2010). Therefore, when individuals who feel that their organizations or supervisors value and support them and treat them fairly, these individuals tend to be more committed to the organization and more satisfied with the jobs (Clark \& James, 1999). A meta-analysis study of Colquitt et al. (2001) reported that procedural justice has positive influence on job satisfaction. However, at cross-level analysis, this relationship has been not examined. Therefore, the following hypothesis is proposed:

$\mathrm{H} 2$ : There is a positive cross-level relationship between procedural justice and satisfaction.

From the procedural justice perspective, it is more likely to observe creativity (Amabile, Barsade, Mueller, $\&$ Staw, 2005). An empirical investigation uncovered the perception of procedural justice and its influence on individual creative performance (Simmons, 2011). It is important that individual employees perceive procedural justice so that they feel valued and are motivated to produce creative work (Oldham \& Cummings, 1996). Clark and James (1999) proposed that procedural justice will help stimulate positive creativity. This is consistent with Dayan and Colak (2008), who suggested that a procedural justice climate has a positive influence on new product creativity. Thus, the following hypothesis is proposed:

H3: There is a positive cross-level relationship between procedural justice and employee creativity.

\section{The Effects of POS}

The concept of POS has been drawn from the social exchange theory, which explains the relationship between employees' behavior and organizational outcomes (Eisenberger et al., 1986; Lio et al., 2006). According to Eisenberger et al. (1986), POS is defined as "The global belief held by an employee that the organization values his/her contributions and cares about their well-being” (p. 501). It is suggested that employee with higher level of POS tends to improve their work attitudes and engender effective work behavior (Hsieh \& Guy, 2009). This sense of supportive organization is committed to its employees to achieve higher performance (Asealage \& Eisenberger, 2003; Rhoades \& Eisenberger, 2002). Most recently, POS enhances individual outcomes, such as trust in organization (e.g., Chen et al., 2005; Tremblay et al., 2010), OCB, leave intention (e.g., Zhang et al., 2011), and affective organizational commitment (e.g., Baranik et al., 2010). However, the link between POS and employee's job engagement has been mostly ignored in the literature. Thus, this relationship was established and explored by the present study at cross-level analysis in high-tech firms.

Social exchange perspective also promotes our understandings on why employees would choose to be less or more engaged in their jobs. It is suggested that when individual employees perceive that their organization cares or supports for their well-being, they would obliged to help the organization reach its goals (Rhoades \& Eisenberger, 2002; Shiu \& Yu, 2010). Saks (2006) reported that POS is positively related to employee's job and organization engagement. Based on above rationale, this study proposes that POS could motivate employees to be more engagement in their jobs (Cheng, Jiang, \& Riley, 2003). Thus, the following hypothesis is proposed: 
$\mathrm{H}$ 4: There is a positive cross-level relationship between POS and job engagement.

POS appears to be a useful theoretical framework for assessing individual behavior in organizations (Rhoades \& Eisenberger, 2002). Conceptually, individual employees with higher levels of POS are more committed to the organizations they work for and more satisfied with their jobs (Petty, McGee, \& Cavender, 1984). At individual-level analysis, research has established the link between POS and job satisfaction (Baranik et al., 2010; Erdogan \& Enders, 2007; Rhoades \& Eisenberger, 2002; Riggle, Edmondson, \& Hansen, 2009). However, this relationship has not examined at a cross-level analysis. With regard to the social support concepts, we expect that a high level of POS received by individual employees will increase their job satisfaction (Cheng et al., 2003; Taris \& Schreurs, 2009). Thus, the following hypothesis is proposed.

H5: There is a positive cross-level relationship between POS and job satisfaction.

The influence of POS is likely to extend to creativity and innovation along with other outcomes, but this possibility has received little empirical attention (Clark \& James, 1999). Similarly, empirical evidences indicated that supportive social relationships in organizations are crucial to predict individual creativity (Talbot, Cooper, \& Barrow, 1992), especially support from top management (Zeldman, 1980). According to the social exchange theory, the support provided by immediate supervisors exerts an influence on subordinates' creativity (Amabile et al., 2004). This notion is similar with the findings of Lin and Liu (2012), report that supervisory encouragement and work group support are significantly related to individual perceived innovation. Based on these reasons, we believe that similar effects may hold for employee creativity. Thus, the following hypothesis is proposed:

H6: There is a positive cross-level relationship between POS and employee creativity.

\section{The Effects of Employee Engagement}

Engagement is an individual-level construct, which lead to and an impact on individual-level outcomes (Saks, 2006). Employee's job engagement is associated with individuals feel obliged to bring themselves more deeply involvement in their role performances (Kahn, 1990). Since the term "employee engagement" has been titled in the way of model or theory development (Saks, 2006). Thus, this study operationalizes the dentition of job involvement as "employee engagement", which refers to the degree to which employee identifies with his or her job, actively involved in it, and express his or her performance important to self-worth (Robbins \& Judge, 2007). In practical terms, engagement may be viewed as an energized satisfaction (Warr \& Inceoglu, 2011). The correlation between employee engagement and job satisfaction have examined in nursing context (e.g., Giallonardo, Wong, \& Iwasiw, 2010; Simpson, 2009), non-specific research context (e.g., Saks, 2006), and undergraduate students at Kansas State University and Midwestern public university (e.g., Alarcon \& Lyons, 2011; Wefald \& Downey, 2009). Although the previous studies do tend to support the hypothesis that engagement and job satisfaction are distinct, however, it remains unclear how an established employee engagement scale relates to job satisfaction, which is mostly ignored to examine in high-tech industry research. Along with these arguments, we assume that employees engaging more in their work will result in higher level of job satisfaction. Thus, the following hypothesis is proposed:

H7: Employee's job engagement positively influences job satisfaction.

Ul-Haq, Ali, Umer-Azeen, Hijazi, Qurashi, and Quyyum (2010) has confirmed that higher employee engagement will result in higher creativity. Ul-Haq et al. (2010) argued that both employee engagement and job satisfaction predict employee creativity at work. In problem solving, when employees are deeply engagement in their job, they are more likely to enhance higher levels of job satisfaction, which in turn to lead them to 
generate more innovative or creative ideas to achieve high performance. If engagement does predict the employee creativity when she/he satisfies with her/his job, it also demonstrates the functional nature of job satisfaction. Therefore, the following hypothesis is proposed:

H8: Job satisfaction partially mediates the relationship between job engagement and employee creativity.

\section{The Effect of Job Satisfaction}

Job satisfaction can be considered as the employees' satisfaction, which reflects the extent to which they enjoy the job (Shiu \& Yu, 2010). Job satisfaction is defined as being a positive feeling about one's job resulting from an evaluation of its characteristics (Robbins \& Judge, 2013). Employees' job satisfaction is one of the most important factors predicting organizational performance (Comm \& Mathaisel, 2006). Existing literature generally assumes that higher job satisfaction is associated with higher individual outcomes (Taris \& Schreurs, 2009; Vermeeren, Kuipers, \& Steijn, 2011). This study outlines that the link between job satisfaction and employee creativity has rarely been explored. Logical thinking, we assume that when employees are satisfied with their job, they would spend more time to work better and more innovatively. Therefore, this study believes that a higher level of job satisfaction is associated with better employee creativity at work. Thus, the following hypothesis is proposed:

H9: Job satisfaction positively influences employee creativity.

\section{Research Framework}

This present conceptual model is expected to contribute to our understanding about how social exchange and organizational justice theories impact on employee's job engagement, satisfaction, and creativity, at cross-level analysis (i.e., H1, H2, H3, H4, H5, and H6). At individual-level analysis (H7, H8, \& H9), the relationship among employee's job engagement, satisfaction, and creativity can be explained by individual creativity theory. The interrelationships among research constructs and the corresponding nine hypotheses are illustrated in Figure 1.

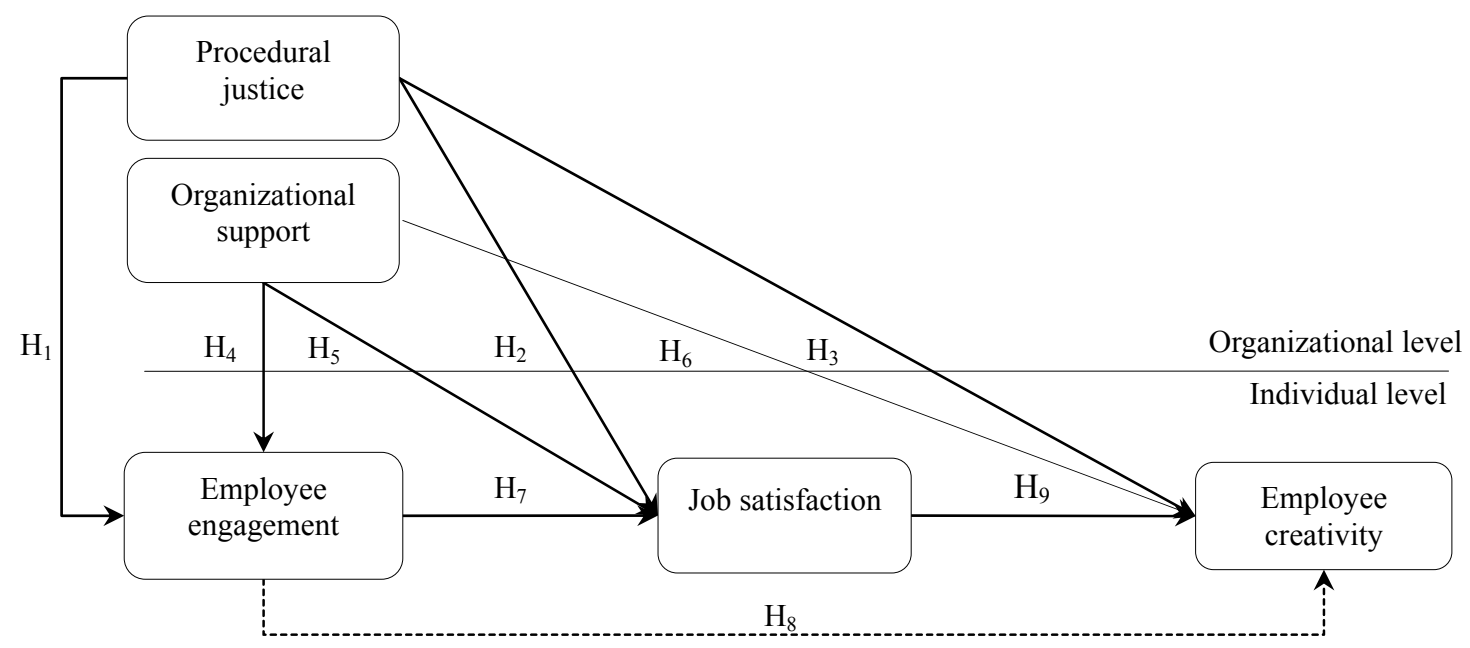

Figure 1. Proposed cross-level framework of employee creativity.

\section{Method}

\section{Measurement Scales}

Procedural justice. According to Loi et al. (2009), and Holtz and Harold (2009), procedural justice was treated at the organizational-level, and six items $(\alpha=0.85)$ were adopted from Scott, Colquitt, and 
Zapata-Phelan (2007). Three employees in R\&D department were invited to rate their manager.

POS. Eight items of POS $(\alpha=0.93)$ were adopted from Rhoades, Eisenberger, and Armeli (2001). This construct was also treated at the organizational level analysis in this study. Three employees in R\&D department were invited to rate overall perceptions of their organizations.

Employee engagement and job satisfaction. At individual analysis, six items $(\alpha=0.87)$ of employee engagement were operationalized from Avery, McKay, and Wilson (2007) and five items of job satisfaction ( $\alpha$ $=0.95$ ) were adopted from Brayfield and Rothe (1951), which were modified by Lambert, Hogan, and Griffin (2007). Three employees in R\&D department were invited to rate these items.

Employee creativity. To reduce common bias issues from data collection procedures, which collected from the same sources (Podsakoff, MacKenzie, \& Podsakoff, 2012). This study asked one manager in R\&D department of each sample firms to rate their three subordinates using six-item scale of employee creativity $(\alpha=0.90)$ from Scott and Bruce (1994). This construct has been treated as individual analysis (e.g., Hon, 2011; Zhang \& Bartol, 2010).

The measurement of questionnaire items was translated from English to Chinese. A standard translation and back-translation procedure was performed to validate the meanings of measurement items and a 7-point Likert scale was used for all research constructs (i.e., from 1 = "Strongly disagree" to 7 = "Strongly agree").

\section{Control Variables}

Two control variables were included in the study: (1) job tenure; and (2) educational background to control of both levels for further analyses.

\section{Sampling Procedures}

Data collection procedure was focused on two level analyses: organizational level (manager/supervisor) and individual level (employees/subordinates). This study selected 200 high-tech firms from the top 1,000 firms as listed by Common Wealth Magazine in Taiwan (2010). Then, a 1:3 matched pairwise of one manager/ supervisor and three subordinates in the R\&D department of each high-tech firm were designed and operated. This procedure consists of two stages: First, the managers of human resource department of each high-tech firm were asked to select one manager and three employees from the R\&D department to participate in our survey. Second, the survey package were sent to the assigned R\&D managers/supervisors to rates measurement items of procedural justice and POS that exercised by the managers/supervisors. The managers/supervisors are also asked to rate their three subordinates with measurement items employee creativity. Then, three assigned subordinates of the assigned managers were asked to rate the measurement items of employee engagement and job satisfaction. A total of 200:600 $(1: 3 \times 200)$ pairwise questionnaires were sent to 200 high-tech firms and 106 were returned. However, 28 matched pairs of samples for the firms (i.e., 28 supervisors/managers and 84 subordinates) were excluded as outliers. The outliers were deleted using the graphical method, which is a residual scatter plot in the range of \pm 3 standard deviation (Hair, Black, Babin, \& Anderson, 2010). Finally, the valid responses received from 78 firms which included 78 supervisors/managers and 234 subordinates (with a response rate of 53\%). Therefore, data from 78 supervisors/managers at the organizational-level and 234 subordinates at individual-level were used for further analysis.

\section{Analytical Strategy}

The ICCs (Intraclass Correlation Coefficients) technique was adopted to assess the interrater reliability of judgments as provided by the R\&D department the high-tech firms. The term "interrater reliability" is used here to refer to the degree to which judges are "inter-changeable", which is to say the extent to which judges 
"agree" on a set of "judgments" (James, Demaree, \& Wolf, 1984, p. 86). In this study, the ICC1 coefficient represents the proportion of variance in ratings at an individual level that is attributed to group membership; whereas the ICC2 coefficient represents the reliability of the group level means (Bliese, 2000).

According to James et al. (1984) and Mathieu, Gilson, and Ruddy (2006), the minimum cut-off value for ICC 1 is 0.12 and for ICC2 is 0.60 . The ICC 1 coefficients were 0.425 for employee engagement, 0.287 for job satisfaction, and 0.412 for employee creativity. The ICC2 coefficients were 0.887 for employee engagement, 0.725 for job satisfaction, and 0.789 for employee creativity, respectively. Taken together, these results showed that the inter-rater (within-group) agreement to be acceptable.

The within-group agreement $\left(r_{w g} s\right)$ was calculated for organizational level of analysis. In the case of the 78 high-tech firms, the mean of their $r_{w g} s$ was 0.91 for procedural justice, 0.96 for POS. All of the mean $r_{w g}$ s were greater than the conventionally accepted value of 0.70 (James, Demaree, \& Wolf, 1993), indicating a reasonable level of agreement.

Hierarchical linear modeling was used to test cross-level effects of relationship within-person (individual level) and between-person (organizational level) (e.g., Hofmann, Giffin, \& Gavin, 2000; Raudenbush \& Bryk, 2002). Thus, this study uses HLM 7 (hierarchical linear modeling) to conduct a cross-level analysis of H1-H6 and SEM (structural equation modeling: AMOS 20) to test H7-H9 at individual-level.

In HLM, level 2 models estimate the intercepts and slopes of between-person relations. To test cross-level effects of H1-H6, we regressed employee engagement, job satisfaction, and creativity onto procedural justice and POS at level 2 and entered control variables (i.e., education and job tenure) at level 1. In these analyses, we centered the level 2 predictor variables at each individual's means. This procedure effectively controls for the potentially confounding effects of between-person (organizational-level) differences on the within-person (individual-level) relationships (e.g., Enders \& Tofighi, 2007; Loi et al., 2009).

At level 1, the pooled values of the level 2 parameters are used as dependent variables that are predicted by the between individual variables (i.e., procedural justice and POS) and control variables. To assess the cross-level effects of between-individual level procedural justice and POS, a precondition of significant variance in the level 2 slopes should be supported (Hofmann, 1997).

\section{Results}

\section{Reliability Tests}

CFA (confirmatory factor analysis) was conducted to assess convergent and construct validity of the measurement model at both organizational and individual levels (Anderson \& Gerbing, 1988). First order-factor model was adopted to examine each individual research construct, the result of these procedures are presented in the Appendix and it indicated that standardized loading for all items exceeded 0.70 and that $t$-values were higher than $1.96(p<0.001)$, which satisfied the threshold as recommended by Hair et al. (2010). Then, second order CFA was conducted to examine overall measurement model of the organizational level (i.e., procedural justice and POS), as shown in Figure 2 and Table 1. The second order CFA of overall measurement model of individual level was also performed (i.e., employee engagement, job satisfaction, and employee creativity), as shown in Figure 3 and Table 2. The results showed the overall goodness-of fit assessment for both level analyses are satisfied with the threshold, which thus demonstrating that the research model can be presented as a good model fit with adequate convergent validity and construct reliability (e.g., Gerbing \& Anderson, 1992; Hair et al., 2010; Kline, 2011; Lu, Lai, \& Cheng, 2007). Therefore, means, standard deviations, 
and correlations among control and research variables of both level analyses are reported in Tables 3 and 4 . Consistent with the literature, each research variable had significant correlations.

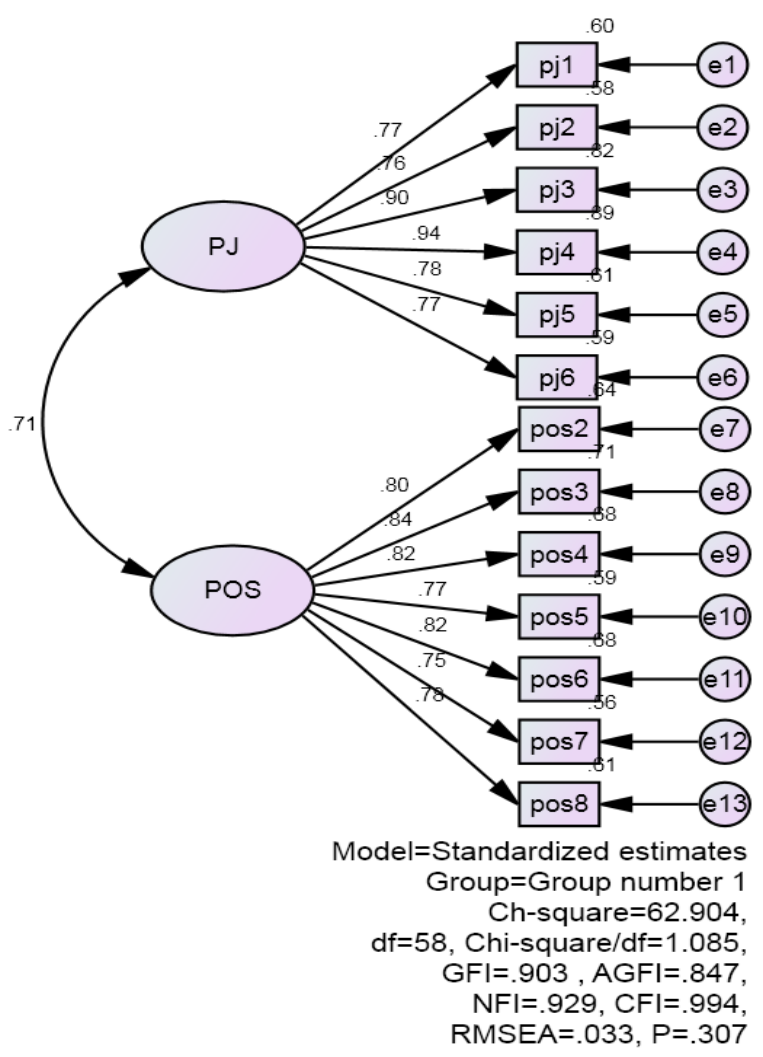

Figure 2. Second order-CFA of organizational level $(N=78)$.

Table 1

Results of CFA (Organizational Level $-N=78$ )

\begin{tabular}{|c|c|c|c|c|}
\hline Construct & Variables & $\begin{array}{l}\text { Standardized } \\
\text { loading }\end{array}$ & $t$-Value & AVE \\
\hline \multicolumn{4}{|c|}{ PJ (procedural justice) } & \multirow[t]{7}{*}{0.680} \\
\hline PJ1 & Job decisions are made by this organization in an unbiased manner. & $0.774^{* * *}$ & 9.591 & \\
\hline PJ2 & $\begin{array}{l}\text { This organization makes sure that all employee concerns are heard before job } \\
\text { decisions are made. }\end{array}$ & $0.761^{* * *}$ & 9.24 & \\
\hline PJ3 & To make job decisions, this organization collects accurate and complete information. & $0.903^{* * *}$ & 13.741 & \\
\hline PJ4 & $\begin{array}{l}\text { This organization clarifies decisions and provides additional information when } \\
\text { requested by employees. }\end{array}$ & $0.943^{* * *}$ & A & \\
\hline PJ5 & All job decisions are applied consistently across all affected employees. & $0.781^{* * *}$ & 9.586 & \\
\hline PJ6 & Employees are allowed to challenge or appeal job decisions made by this organization. & $0.766^{* * *}$ & 9.217 & \\
\hline POS & & & & \multirow[t]{9}{*}{0.637} \\
\hline POS1 & This organization really cares about my well-being. & $0.800^{* * *}$ & A & \\
\hline POS2 & This organization strongly considers my goals and values. & $0.843^{* * *}$ & 8.545 & \\
\hline POS3 & This organization shows little concern for me. ${ }^{\text {(Reversed code) }}$ & $0.823^{* * *}$ & 8.273 & \\
\hline POS4 & This organization cares about my opinions. & $0.765^{* * *}$ & 7.547 & \\
\hline POS5 & This organization is willing to help me if I need a special favor. & $0.823^{* * *}$ & 8.265 & \\
\hline POS6 & Help is available from this organization when I have a problem. & $0.748^{* * *}$ & 7.236 & \\
\hline POS7 & This organization would forgive an honest mistake on my part. & $0.781^{* * *}$ & 7.694 & \\
\hline POS8 & If given the opportunity, this organization would take advantage of me. (Reversed code) & $<0.60$ & Deleted & \\
\hline
\end{tabular}




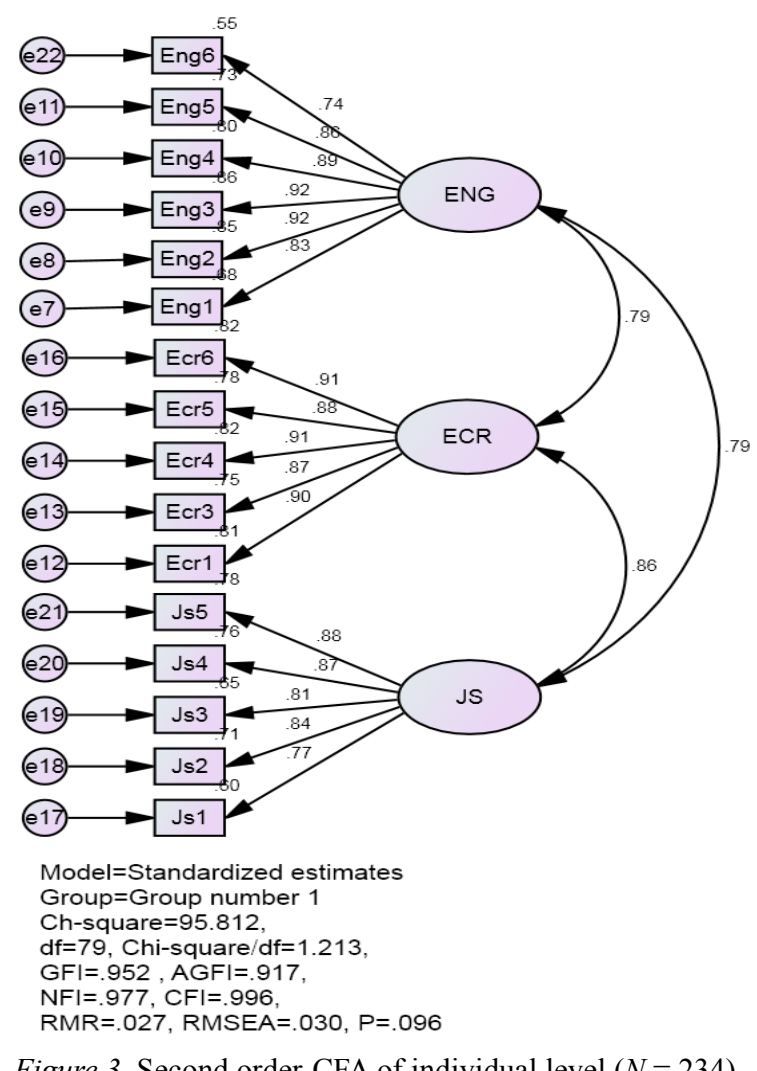

Figure 3. Second order-CFA of individual level $(N=234)$.

Table 2

Results of CFA (Employee Level $-N=234$ )

\begin{tabular}{|c|c|c|c|c|}
\hline Construct & Variables & $\begin{array}{l}\text { Standardized } \\
\text { loading }\end{array}$ & $t$-Value & AVE \\
\hline \multicolumn{4}{|c|}{ ENG (employee engagement) } & \multirow[t]{7}{*}{0.744} \\
\hline Eng1 & I spend much effort to engage in my job. & $0.827^{* * *}$ & 18.623 & \\
\hline Eng2 & I spend considerable time trying to do my work right. & $0.921^{* * *}$ & 24.987 & \\
\hline Eng3 & I often think about having greater opportunities at work to learn and grow. & $0.923^{* * *}$ & A & \\
\hline Eng4 & The company's mission makes me feel my job is important. & $0.892^{* * *}$ & 22.775 & \\
\hline Eng5 & I am highly committed to improving quality work. & $0.855^{* * *}$ & 20.21 & \\
\hline Eng6 & My supervisor/fellow employees encourage my job development. & $0.745^{* * *}$ & 15.297 & \\
\hline \multicolumn{4}{|c|}{ JS (job satisfaction) } & \multirow[t]{6}{*}{0.699} \\
\hline Js1 & I feel fairly well satisfied with my job. & $0.770^{* * *}$ & 14.813 & \\
\hline Js2 & I find real enjoyment in my job. & $0.840^{* * *}$ & 17.592 & \\
\hline Js 3 & Most days I am enthusiastic about my job. & $0.810^{* * *}$ & 16.327 & \\
\hline Js4 & I like my job better than the average worker does. & $0.871^{* * *}$ & 18.726 & \\
\hline Js5 & I definitely dislike my job ${ }^{\text {(Reverse coded). }}$ & $0.885^{* * *}$ & A & \\
\hline \multicolumn{4}{|c|}{ ECR (employee creativity) } & \multirow[t]{7}{*}{0.665} \\
\hline Ecr1 & We encourage and emphasize or reinforce creativity by employees. & $0.902^{* * *}$ & 19.506 & \\
\hline Ecr2 & We respect employees' ability to function creatively. & $0.869^{* * *}$ & 20.333 & \\
\hline Ecr3 & We allow employees to try to solve the same problems in different ways. & $0.907^{* * *}$ & A & \\
\hline Ecr4 & We expect employees to deal with problems in different ways. & $0.882^{* * *}$ & 21.06 & \\
\hline Ecr5 & We will reward employees who are creative in doing their job. & $0.907^{* * *}$ & 22.585 & \\
\hline Ecr6 & We will publicly recognize those who are creative. & $0.902^{* * *}$ & 19.506 & \\
\hline
\end{tabular}


Table 3

Correlation Matrix of Research Variables (Supervisor Level $-N=78$ )

\begin{tabular}{|c|c|c|c|c|c|c|}
\hline Variables & Mean & $S D$ & 1 & 2 & 3 & 4 \\
\hline 1. POS & 5.039 & 1.025 & 0.928 & & & \\
\hline 2. PJ & 4.842 & 1.140 & $0.697^{* *}$ & 0.926 & & \\
\hline 3. Education & 1.410 & 0.746 & 0.023 & -0.007 & $\mathrm{n} / \mathrm{a}$ & \\
\hline 4. Job tenure & 1.513 & 0.785 & -0.119 & -0.152 & $0.589^{* *}$ & $\mathrm{n} / \mathrm{a}$ \\
\hline
\end{tabular}

** Correlation is significant at the 0.01 level (2-tailed).

Notes. ${ }^{* * *}$ Correlation is significant at the 0.01 level (2-tailed); Internal consistency reliabilities appear as bold numbers along the diagonal, $\mathrm{n} / \mathrm{a}=$ Not available.

Table 4

Correlation Matrix of Research Variables (Employee Level- $N=234$ )

\begin{tabular}{llllllll}
\hline Variables & Mean & $S D$ & 1 & 2 & 3 & 4 & 5 \\
\hline 1. ENG & 4.187 & 1.138 & 0.942 & & & & \\
2. JS & 3.799 & 0.800 & $0.771^{* *}$ & 0.926 & & & \\
3. ECR & 4.687 & 0.991 & $0.761^{* *}$ & $0.797^{* *}$ & 0.939 & & \\
4. Education & 1.594 & 0.819 & 0.056 & 0.056 & 0.01 & $\mathrm{n} / \mathrm{a}$ & \\
5. Job tenure & 1.539 & 0.753 & $0.146^{*}$ & $0.148^{*}$ & $0.206^{* *}$ & $0.453^{* *}$ & $\mathrm{n} / \mathrm{a}$ \\
\hline
\end{tabular}

Notes. ${ }^{* *}$ Correlation is significant at the 0.01 level (2-tailed); ${ }^{*}$ Correlation is significant at the 0.05 level (2-tailed); Internal consistency reliabilities appear as bold numbers along the diagonal, $\mathrm{n} / \mathrm{a}=$ Not available.

\section{Hypotheses Testing}

HLM (cross-level hypotheses). To determine if the variance in slopes at level 2 was related to procedural justice and perceived organizational justice (H1-H6), we first examined an intercepts-as-outcomes model as a preliminary model, which includes procedural justice and perceived organizational justice as predictors of employee engagement, job satisfaction, and employee creativity, respectively. This procedure provided a baseline model for illustrating the change in explained variance $\left(R^{2}\right)$ in the level 1 slopes with the addition of the interaction terms. Then, we examined a slopes-as-outcomes model at level 2 . Table 5 provides a summary of the models and results used to test H1-H6. We controlled for job tenure and education in our tests of each hypothesis. Only, job tenure and education were significant in the model for $\mathrm{H} 3\left(\gamma_{10}=0.075\right.$ and $\left.\gamma_{10}=0.081, p<0.05\right)$.

The findings indicated that procedural justice has positive and significant effect on employee engagement $\left(\gamma_{01}=0.284, p<0.01, R^{2}=0.267\right)$, job satisfaction $\left(\gamma_{01}=0.553, p<0.001, R^{2}=0.392\right)$, and creativity $\left(\gamma_{01}=\right.$ $0.519, p<0.001, R^{2}=0.307$ ), which provided support for $\mathrm{H} 1, \mathrm{H} 2$, and $\mathrm{H} 3$, respectively. As can be seen in Table 5 that, results showed that POS also has a positive and significant influence on employee engagement $\left(\gamma_{01}=0.366, p<0.001, R^{2}=0.208\right)$, job satisfaction $\left(\gamma_{01}=0.647, p<0.001, R^{2}=0.367\right)$, and employee creativity $\left(\gamma_{01}=0.511, p<0.001, R^{2}=0.289\right)$, which confirmed $\mathrm{H} 4$, H5, and $\mathrm{H} 6$, respectively.

SEM. SEM was adopted to test the maximum likelihood estimate method and $\mathrm{H} 7-\mathrm{H} 9$. The results showed (see Figure 4 and Table 6) that $\chi^{2}=106.676 ; d f=80$; GFI $=0.945 ; \mathrm{AGFI}=0.907 ; \mathrm{RMR}=0.033$, and $p=0.025$, all of which satisfied the threshold as suggested by Hair et al. (2010). H7 predicted employee engagement to have a positive effect on job satisfaction. The findings provided support for $\mathrm{H} 7(\beta=0.80, p<0.001, t=12.827)$. $\mathrm{H} 9$ predicted job satisfaction to have a positive effect on employee creativity. The results provided support H9 $(\beta=0.69, p<0.001, t=8.715)$. Finally, the prediction of the effect of employee engagement and employee creativity has confirmed and provided partially support for $\mathrm{H} 8(\beta=0.22, p<0.01, t=3.151)$. As suggested by Baron and Kenny's test (1986) (i.e., structural models of: First, independent variable must be shown to be significant related to the mediator; Second, independent variable must be shown to be significant related to the 
dependent variable; and Third, mediator must affect the dependent variable) which indicated that job satisfaction has partially mediated the relationship between employee and employee creativity. This notion is in line with Sobel's test (1982) illustrated that $z$-test statistic must be exceeded a value of $t$-test $=1.96$, which indicated that mediator effect exists. In this study $z$-test $=6.151(p<0.001)>1.96$. Therefore, we assume that job satisfaction plays an important role as mediating effect, as proposed in $\mathrm{H} 8$.

Table 5

Hierarchical Linear Modeling Results for Procedural Justice and POS

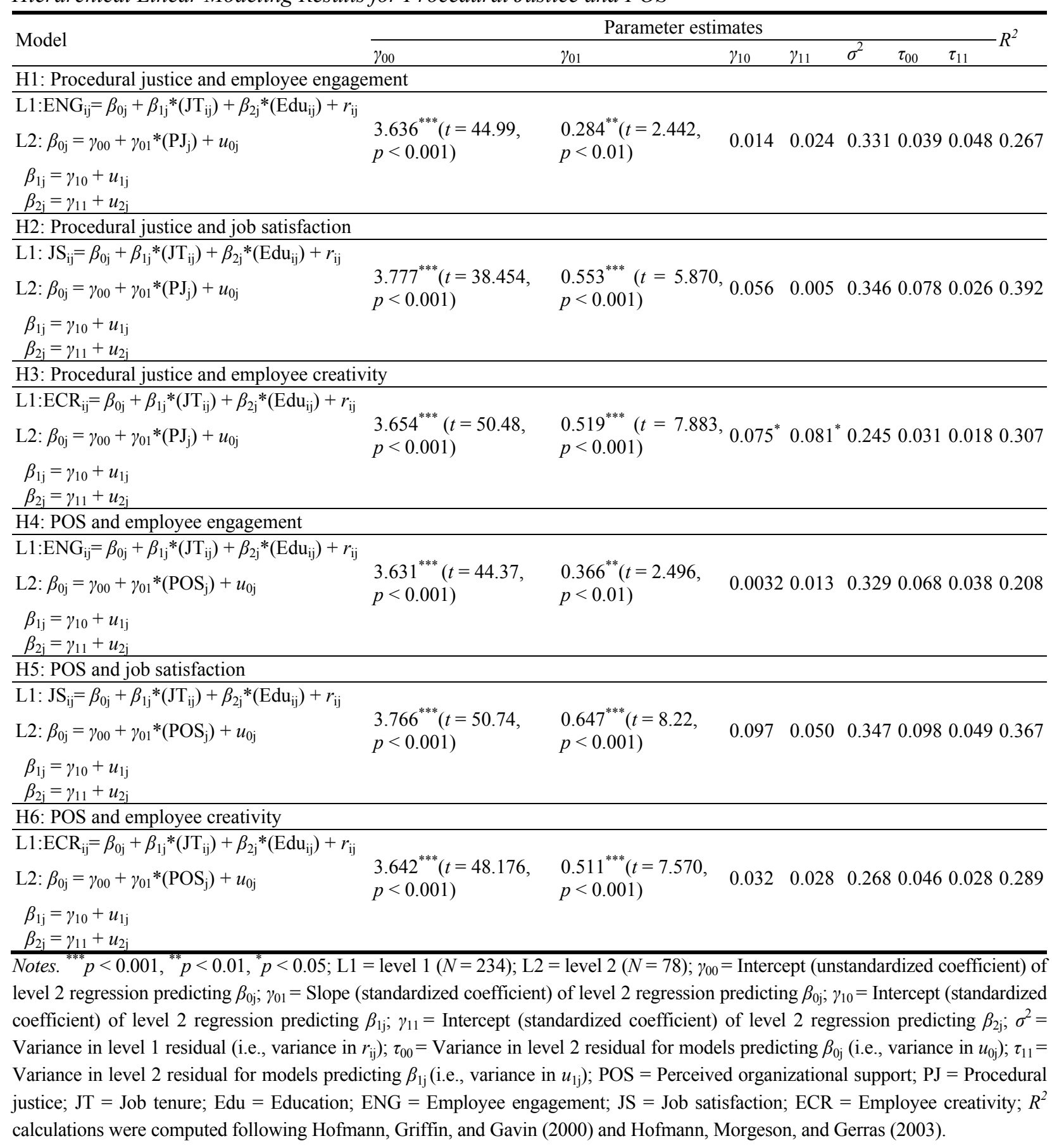




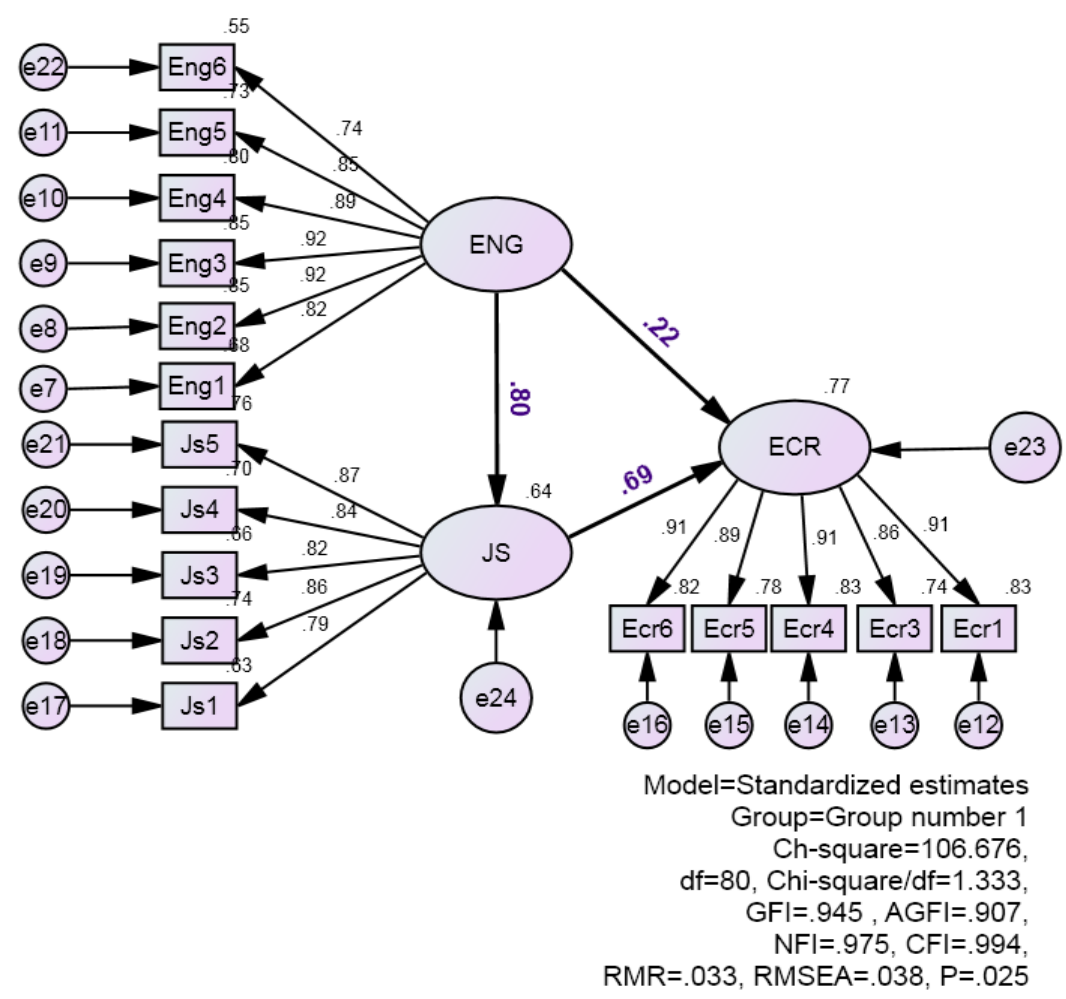

Figure 4. Structural model of individual level $(N=234)$.

Table 6

Path Coefficient of Structural Model

\begin{tabular}{|c|c|c|c|c|}
\hline Path relationship & Standardized coefficient & SE & $t$-Value & $p$ \\
\hline H7: Employee engagement $\rightarrow$ Job satisfaction & $0.80^{* * *}$ & 0.039 & 12.827 & $<0.001$ \\
\hline H9: Job satisfaction $\rightarrow$ Employee creativity & $0.69^{* * *}$ & 0.107 & 8.715 & $<0.001$ \\
\hline H8: Employee engagement $\rightarrow$ Employee creativity & $0.22^{* *}$ & 0.059 & 3.151 & 0.002 \\
\hline \multicolumn{5}{|l|}{ Goodness of fit assessment } \\
\hline Chi-square $\left(\chi^{2}\right)$ & $=106.676(p=0.025)$ & & & \\
\hline$d f$ & $=80$ & & & \\
\hline GFI & $=0.945$ & & & \\
\hline AGFI & $=0.907$ & & & \\
\hline RMR & $=0.033$ & & & \\
\hline
\end{tabular}

\section{Discussion}

In a case of the analysis of cross-level, the effects of procedural justice on employee engagement, job satisfaction, and employee creativity were confirmed by this study, such as $\mathrm{H} 1\left(\gamma_{01}=0.284, p<0.01, R^{2}=\right.$ $0.267), \mathrm{H} 2\left(\gamma_{01}=0.553, p<0.001, R^{2}=0.392\right)$, and H3 ( $\left.\gamma_{01}=0.519, p<0.001, R^{2}=0.307\right)$, respectively. Conceptually, these relationship have been mostly ignored with regard to empirical testing, therefore, this study may lack the evidence to support the present findings. Since previous studies have fail to discover the effect of procedural justice on employee's job engagement in individual analysis at non-specific research context (e.g., Saks, 2006) and cross-sectional of service contexts in Malaysia (e.g., Sze \& Angeline, 2011). Thus, the findings 
of this study were confirmed at cross-level analysis of employee-supervisor pairs in high-tech industries. This finding is also in line with previous findings at individual analysis, such as Saks (2006) used unspecific samples, McFarlin and Sweeney (1992) used student samples, Hon and Lu (2010) examinedexpatriate outcomes, and cross-sectional survey about complaint handling experiences of passengers waiting (e.g., Ambrose, Hess, \& Ganesan, 2007). The effect of procedural justice on employee creativity was confirmed in this study, while this effect at individual analysis was uncovered by Simmons (2011) in a study of doctoral students.

To verify whether the POS has a positive and significant on employee engagement, job satisfaction, and employee creativity, the results of the analysis provided support for $\mathrm{H} 4\left(\gamma_{01}=0.366, p<0.001, R^{2}=0.208\right)$, H5 $\left(\gamma_{01}=0.647, p<0.001, R^{2}=0.367\right)$, and H6 $\left(\gamma_{01}=0.511, p<0.001, R^{2}=0.289\right)$, respectively. The link between POS and employee engagement was confirmed by this study at cross-level analysis. This finding is also in line with previous empirical findings at individual analysis, which proposed that social exchange perspectives (i.e., POS) (e.g., Saks, 2006), and supervisory support have a positive influence on employee work engagement (e.g., Menguc, Auh, Fisher, \& Haddad, 2012), and job engagement (e.g., Sze \& Angeline, 2011). At individual level analysis, the relationship between POS and job satisfaction has been empirical examined by previous studies on a variety of research contexts (e.g., Ambrose \& Schminke, 2009; Baranik et al., 2010; Begley et al., 2006; Erdogan \& Enders, 2007; Loi et al., 2009; Rhoades \& Eisenberger, 2002; Riggle et al., 2009). However, at cross-level analysis, this relationship is confirmed by this study. In previous extension literature of POS, cross-level effects of relationship between POS and employee creativity has been very rare. These study results are in line with a few findings in the social exchange literature, which posited that the support provided supervisor has a positive influence on subordinate's work creativity (Amabile et al., 2004), and supervisory encouragement and work group support are positively related to individual perceived work innovation (Lin \& Liu, 2012).

In summary, the findings of this study at cross-level analysis were validated previous empirical evidences which examined at individual analysis. According to the extension theory of social exchange, we can conclude that POS and procedural justice play very critical role in explaining individual behavior and outcomes at cross-level analysis. Based on the findings of this study, it is indicated that supervisors/managers in the R\&D of each high-tech firm has similar perceptions on how to treat and encourage their subordinates to achieve work performance. On the other hand, individual employees with higher levels of support and justice or fair treatment from managers in work units seem to be key sources to build high level of individual's commitment to job engagement, satisfaction, and creativity at work.

\section{Managerial Implications}

The aim of this study was to enable managers to adopt more appropriate work practices to enhance individual employee's job engagement and thereby their job satisfaction and creativity at work. This research provides additional evidence to support the limited amount in the literature of organizational justice indicating that procedural justice of treatment can influence employee engagement, job satisfaction and employee creativity (Clark \& James, 1999). The extension literature of the social exchange theory also confirmed that POS can predict employee engagement, job satisfaction, and employee creativity at cross-level analysis in high-tech context. Thus, this study contributes to cross-effects that employee-supervisor pairs can be explained by the social exchange and organizational justice theories. The findings of this study are to provide 
manager-employee dyadic relationship with some efforts for decision-making process, using fair procedures to enhance employee performance (Zapata-Phelan, Colquitt, Scott, \& Livingston, 2009).

From another perspective, the findings of this study also indicated that fair treatment and high level support from organization either among supervisors or between supervisor and subordinates are key resources by which to increase employee retention, and reduce turnover intention (e.g., Alarcon \& Edwards, 2011; Paré $\&$ Tremblay, 2007). When subordinates feel satisfied with the fairness of treatment and higher levels of support from their working unit, they tend to have higher levels of organizational commitment, as well as lower levels of work conflict and job stress (e.g., Baranik et al., 2010; Tremblay et al., 2010). In line with previous study, procedural justice leads to promote better perceptions of legitimacy and trust in the organization (Lambert et al., 2007). According to Farme, Tierney, and Kung-McIntyre (2003, p. 377), "If employees view procedures as fair, they may view the organization positively (commitment), even if they are currently dissatisfied with such personal outcomes". Basically, it is imperative for correctional organizational support and fair treatment to recognize those characteristics of the organization that contribute to a less stressed, more satisfied and committed to engaging in workforce, which may lead to increase more work creativities. Therefore, it is expected that these additional findings may be good resources to enhance the relationship between employees and managers/organizations at work units. It is also believed that a better understanding of matched employee-manager pair relationships is very important for building human and social capital in organizational learning and justice context.

\section{Limitations and Future Research}

This study integrates a comprehensive model to investigate employee-supervisor/or manager dyadic relationship at high-tech industries, by extending theories of social exchange and organizational justice. These theories revealed that procedural justice and POS can predict individual employee outcomes, such as job engagement, satisfaction, and creativity. However, a few limitations were still recognized by this study that may provide better development for future research. First, this study suspects that employee engagement may play an important role as mediator for the influences of procedural justice on employee creativity and job satisfaction. For example, the influence of each procedural justice is first on job satisfaction, and through employee attitudes toward work engagement (Lambert et al., 2007). Thus, it is suggested that further research should examine cross-mediating effects in order to better provide additional findings which can enhance the validity and generalizability of the current findings. We hope this study will stimulate further interest in examining the effects of support and justice on both level analyses.

Second, since our research samples focus on Chinese context, this study suspects that leadership styles (i.e., transformational) (e.g., Gong, Huang, \& Farh, 2009), empowerment leadership (e.g., Zhang \& Bartol, 2010), and cross-cultural differences (i.e., individualism vs. collectivism, and power distance) (e.g., Hofstede, 1980; Kirkman, Chen, Farh, \& Lowe, 2009) may influence individual employee outcomes, such asemployee creativity. Thus, the above variables should be included for future study. Third, at both organizational and individual level analyses, most justice research ignores the relationships among employee engagement, job satisfaction, and employee creativity. Thus, the findings of this study are also in lack of empirical support from previous studies. Future research can extend this framework to study on cross-sectional contexts, such as using samples from the United States, European, and other Asia countries in order to achieve generalizability of research findings. 
Fourth, this study focuses on employee-supervisor pairs in the R\&D department of high-tech firms in Taiwan, which seems to be a small portion for representing for total staffs of such high-tech firms. It is suggested that future research should take a closer look at cross-functional units or teams rather than single units alone. Cross-functional units (i.e., R\&D, marketing, and production department) may enhance individual employees to come up with developing and creating useful ideas to perform their job effectively. As suggested by Lussier and Achua (2007), cross-functional units/teams are brought together to perform unique tasks to create innovative product designed to achieve high levels of organizational performance and satisfy customers.

Fifth, future studies should explore not only the impact of POS and procedural justice on employee's job engagement, satisfaction, and creativity, but also the impact of POS and procedural justice on other areas of employee behaviors, such as life satisfaction, psychological and emotional withdrawal from the job, intention to quit, turnover, and absenteeism (Lambert et al., 2007). Finally, a basic direction for future research is to determine whether organizational expectations and individual outcomes other than those constructs that examined here in this study will yield similar predictive patterns for procedural justice and organizational support (McFarlin \& Sweeney, 1992). It is suggested that a more accurate conceptualization of the extension literature of social exchange, and procedural justice will better serve both researchers and practitioners in understanding the impact of justice or fair procedures in organizations (Ambrose et al., 2007; Ambrose \& Schminke, 2009). Organizations should encourage managers to enhance quality relationship, which may in turn foster POS and fairness procedures to increase subordinates attitudes and behavior at workplace.

\section{References}

Alarcon, G. M., \& Edwards, J. M. (2011). The relationship of engagement, job satisfaction and turnover intentions. Stress and Health, 27(3), e294-e298.

Alarcon, G. M., \& Lyons, J. B. (2011). The relationship of engagement and job satisfaction in working samples. The Journal of Psychology, 145(5), 463-480.

Alexander, S., \& Ruderman, M. (1987). The role of procedural and distributive justice in organizational behavior. Social Justice Research, 1(2), 177-198.

Amabile, T. M., Barsade, S. G., Mueller, J. S., \& Staw, B. M. (2005). Affect and creativity at work. Administrative Science Quarterly, 50(3), 367-403.

Amabile, T. M., Schatzel, E. A., Moneta, G. B., \& Kramer, S. J. (2004). Leader behaviors and the work environment for creativity: Perceived leader support. The Leadership Quarterly, 15(1), 5-32.

Ambrose, M. L., Hess, R. L., \& Ganesan, S. (2007). The relationship between justice and attitudes: An examination of justice effects on event and system-related attitudes. Organizational Behavior and Human Decision Processes, 103(1), 21-36.

Ambrose, M. L., \& Schminke, M. (2009). The role of overall justice judgments in organizational justice research: A test of mediation. Journal of Applied Psychology, 94(2), 491-500.

Anderson, J. C., \& Gerbing, D. W. (1988). Structural equation modeling in practice: A review and recommended two-step approach. Psychological Bulletin, 103(3), 411-423.

Ang, S., Van Dyne, L., \& Begley, T. M. (2003). The employment relationships of foreign workers versus local employees: A field study of organizational justice, job satisfaction, performance, and OCB. Journal of Organizational Behavior, 24(5), 561-583.

Aryee, S., Budhwar, P. S., \& Chen, Z. X. (2002). Trust as a mediator of the relationship between organizational justice and work outcomes: Test of a social exchange model. Journal of Organizational Behavior, 23(3), 267-285.

Asealage, J., \& Eisenberger, R. (2003). Perceived organizational support and psychological contracts: A theoretical integration. Journal of Organizational Behavior, 24(4), 491-509.

Avery, D. R., McKay, P. F., \& Wilson, D. C. (2007). Engaging the aging workforce: The relationship between perceived age similarity, satisfaction with coworkers, and employee engagement. Journal of Applied Psychology, 92(6), 1542-1556. 
Baranik, L. E., Roling, E. A., \& Eby, L. T. (2010). Why does mentoring work? The role of perceived organizational support. Journal of Vocational Behavior, 76(3), 366-373.

Baron, R. M., \& Kenny, D. A. (1986). The moderator-mediator variable distinction in social psychological research: Conceptual, strategic, and statistical considerations. Journal of Personality and Social Psychology, 55(6), 1173-1182.

Begley, T. M., Lee, C., \& Hui, C. (2006). Organizational level as a moderator of the relationship between justice perceptions and work-related reactions. Journal of Organizational Behavior, 27(6), 705-772.

Bies, R. J. (2005). Are procedural justice and interactional justice conceptually distinct? In J. Greenberg, \& J. A. Colquitt (Eds.), Handbook of organizational justice (pp. 85-112). New Jersey: Psychology Press.

Blau, P. M. (1964). Exchange and power in social life. New York: Academic Press.

Bliese, P. D. (2000). Within-group agreement, non-independence, and reliability: Implications for data aggregation and analyses. In K. J. Klein, \& S. W. J. Kozlowski (Eds.), Multilevel theory, research, and methods in organizations: Foundations, extensions, and new directions. San Francisco: Jossey-Bass.

Brayfield, A. H., \& Rothe, H. F. (1951). An index of job satisfaction. Journal of Applied Psychology, 35(5), 307-311.

Casper, W. J., Harris, C., Taylor-Bianco, A., \& Wayne, J. H. (2011). Work-family conflict, perceived supervisor support and organizational commitment among Brazilian professionals. Journal of Vocational Behavior, 79(3), 640-652.

Chen, Z. X., Aryee, S., \& Lee, C. (2005). Test of a mediation model of perceived organizational support. Journal of Vocational Behavior, 66(3), 457-470.

Cheng, B. S., Jiang, D. Y., \& Riley, J. H. (2003). Organizational commitment, supervisory commitment, and employee outcomes in the Chinese context: Proximal hypothesis or global hypothesis? Journal of Organizational Behavior, 24(3), 313-334.

Clark, K., \& James, K. (1999). Justice and positive and negative creativity. Creativity Research Journal, 12(4), 311-320.

Cohen, A., \& Veled-Hecht, A. (2010). The relationship between organizational socialization and commitment in the workplace among employees in long-term nursing care facilities. Personnel Review, 39(5), 537-556.

Colquitt, J. A., Conlon, D. E., Wesson, M. J., Porter, C. O. L. H., \& Yee-Ng, K. (2001). Justice at the millennium: A meta-analytic review of 25 years of organizational justice research. Journal of Applied Psychology, 86(3), 425-445.

Colquitt, J. A., \& Greenberg, J. (2003). Organizational justice: A fair assessment of the state of the literature. In J. Greenberg (Ed.), Organizational behavior: The state of the science (pp. 165-210). Mahwah, N.J.: Erlbaum.

Comm, C. L., \& Mathaisel, D. F. X. (2006). Accessing employee satisfaction in service firms: An example in higher education. Journal of Business and Economic Studies, 6(1), 43-53.

Dayan, M., \& Colak, M. (2008). The role of procedural justice in the new product development process. European Journal of Innovation Management, 11(2), 199-218.

Eisenberger, R., Huntington, R., \& Sowa, D. (1986). Perceived organizational support. Journal of Applied Psycology, 71(3), 500-507.

Enders, C. K., \& Tofighi, D. (2007). Centering predictor variables in cross-sectional multilevel models: A new look at an old issue. Psychological Methods, 12(2), 121-138.

Erdogan, B., \& Enders, J. (2007). Support from the top: Supervisors' perceived organizational support as a moderator of leader-member exchange to satisfaction and performance relationships. Journal of Applied Psychology, 92(2), 321-330.

Farmer, S. M., Tierney, P., \& Kung-McIntyre, K. (2003). Employee creativity in Taiwan: An application of role identity theory. Academy of Management Journal, 46(5), 618-630.

George, J. M., \& Jones, G. R. (2008). Understanding and managing organizational behavior (5th ed.). New Jersey, N.J.: Pearson Prentice Hall.

Gerbing, D. W., \& Anderson, J. C. (1992). Monte Carlo evaluations of goodness of fit indices for structural equation models. Social Methods \& Research, 21, 132-160.

Giallonardo, L. M., Wong, C. A., \& Iwasiw, C. L. (2010). Authentic leadership of preceptors: predictor of new graduate nurses' work engagement and job satisfaction. Journal of Nursing Management, 18(8), 993-1003.

Gong, Y., Huang, J. C., \& Farh, J. L. (2009). Employee learning orientation, transformational leadership, and employee creativity: The mediating role of employee creative self-efficacy. Academy of Management Journal, 52(4), 765-778.

Greenberg, J. (1993). The social side of fairness: Interpersonal and informational classes of organizational justice. In R. Cropanzano (Ed.), Justice in the workplace: Approaching fairness in human resource management (pp. 79-103). Hilsdale, N.J.: Lawrence Erlbaum Association.

Greenberg, J. (1993). The social side of fairness: Interpersonal and informational classes of organizational justice. In R. Corpanzano (Ed.), Justice in the workplace: Approaching fairness in human resource management. N.J.: Erlbaum: Hillsdale. 
Hair, J., Black, W., Babin, B. J., \& Anderson, R. E. (2010). Multivariate data analysis (7th ed.). New Jersey: Prentice Hall.

Hofmann, D. A. (1997). An overview of the logic and rationale of hierarchical linear models. Journal of Management, 23(6), 723-744.

Hofmann, D. A., Giffin, M. A., \& Gavin, M. B. (2000). The application of hierachical linear modeling to organizational research. In K. J. Klein, \& S. W. J. Kozlowski (Eds.), Multilevel theory, research, and methods in organization: Foundation, extensions, and directions. San Francisco: Jossey-Bass.

Hofmann, D. A., Griffin, M. A., \& Gavin, M. B. (2000). The application of hierachical linear modeling to organizational research. In K. J. Klein, \& S. W. J. Kozlowski (Eds.), Multilevel theory, research, and methods in organizations. New York: Jossey-Bass.

Hofmann, D. A., Morgeson, F. P., \& Gerras, S. J. (2003). Climate as a moderator of the relationship between leader-member exchange and content specific citizenship: Safety climate as an exemplar. Journal of Applied Psychology, 88(1), 170-178.

Hofstede, G. (1980). Cultural consequences: International differences in work-related value. London: Sage

Holtz, B., \& Harold, C. M. (2009). Fair today, fair motorrow? A longitudinal investigation of overall justice perceptions. Journal of Applied Psychology, 94(5), 1185-1199.

Hon, A. H. Y. (2011). Enhancing employee creativity in the Chinese context: The mediating role of employee self-concordance. International Journal of Hospitality Management, 30(2), 375-384.

Hon, A. H. Y., \& Lu, L. (2010). The mediating role of trust between expatriate procedural justice and employee outcomes in Chinese hotel industry. International Journal of Hospitality Management, 29(4), 669-676.

Hsieh, C. W., \& Guy, M. E. (2009). Performance outcomes: The relationship between anaging the "heart" and managing client satisfaction. Review of Public Personnel Administration, 29(1), 41-57.

James, L. R., Demaree, R. G., \& Wolf, G. (1984). Estimating within-group interater reliability with and without response bias. Journal of Applied Psychology, 69(1), 85-98.

James, L. R., Demaree, R. G., \& Wolf, G. (1993). Rwg: An assessment of within-group interrater agreement. Journal of Applied Psychology, 78(5), 306-309.

Judge, T. A., \& Colquitt, J. A. (2004). Organizational justice and stress: The mediating role of work-family conflict. Journal of Applied Psychology, 89(3), 395-404.

Kahn, W. A. (1990). Psychological conditions of personal engagement and disengagement at work. Academy of Management Journal, 33(4), 692-724.

Kirkman, B. L., Chen, G., Farh, J. L., \& Lowe, K. B. (2009). Individual power distance orientation and follower reactions to transformational leaders: A cross-level, cross-cultural examination. Academy of Management Journal, 52(4), 744-764.

Klendauer, R., \& Deller, J. (2009). Organizational justice and managerial commitment in corporate mergers. Journal of Managerial Psychology, 24(1), 29-45.

Kline, R. B. (2011). Principles and practice of structural equation modeling (3rd ed.). New York: Guilford Press.

Lambert, E. G., Hogan, N. L., \& Griffin, M. L. (2007). The impact of distributive and procedural justice on correctional staff job stress, job satisfaction, and organizational commitment. Journal of Criminal Justice, 35(6), 644-656.

Lin, C. Y. Y., \& Liu, F. C. (2012). A cross-level analysis of organizational creativity climate and perceived innovation: The mediating effect of work motivation. European Journal of Innovation Management, 15(1), 55-76.

Lio, R., Hang-yue, N., \& Foley, S. (2006). Linkaging employee's justice perceptions to organizational commitment and intention to leave: The mediating role of perceived organizational support. Journal of Occupational and Organizational Psychology, $79(1), 101-120$.

Loi, R., Yang, J., \& Diefendorff, J. M. (2009). Four-factor justice and daily job satisfaction: A multilevel investigation. Journal of Applied Psychology, 94(3), 770-781.

Lu, C. S., Lai, K. H., \& Cheng, T. C. E. (2007). Application of structural equation modeling to evaluate the intention of shippers to use Internet services in liner shipping. European Journal of Operational Research, 180(2), 845-867.

Lussier, R. N., \& Achua, C. F. (2007). Effective leadership (3rd ed.). Canada: Thomson South-Western.

Maslach, C., Schaufeli, W. B., \& Leiter, M. P. (2001). Job burnout. Annual Review of Psychology, 52(1), 397-422.

Mathieu, J. E., Gilson, L. L., \& Ruddy, T. M. (2006). Empowerment and team effectiveness: An emperical test of an intergrated model. Journal of Applied Psychology, 91(1), 97-108.

McFarlin, D. B., \& Sweeney, P. D. (1992). Distributive and procedural justice as predictors of satisfaction with personal and organizational outcomes. Academy of Management Journal, 35(3), 626-637. 
Menguc, B., Auh, S., Fisher, M., \& Haddad, A. (2012). To be engaged or not to be engaged: The antecedents and consequences of service employee engagement. Journal of Business Research (in Press).

Moon, H., Kamdar, D., Mayer, D. M., \& Takeuchi, R. (2008). Me or we? The role of personality and justice as other-centered antecedents to innovative citizenship behaviors within organization. Journal of Applied Psychology, 93(1), 84-94.

Oldham, G. R., \& Cummings, A. (1996). Employee creativity: Personal and contextual factors at work. Academy of Management Journal, 39(3), 607-634.

Paré, G., \& Tremblay, M. (2007). The influence of high-involvement human resources practices, procedural justice, organizational commitment, and citizenship behaviors on information technology professionals' turnover intentions. Group \& Organization Management, 32(3), 326-357.

Petty, M. M., McGee, G. W., \& Cavender, J. W. (1984). A meta-analysis of the relationships between individual job satisfaction and individual performance. Academy of Management Review, 9(4), 712-721.

Podsakoff, P. M., MacKenzie, S. B., Lee, J. Y., \& Podsakoff, N. P. (2003). Common method biases in behavioral research: A critical review of the literature and recommended remedies. Journal of Applied Psychology, 88(5), 879-903.

Raudenbush, S. W., \& Bryk, A. S. (2002). Hierarchical linear models: Applications and data analysis methods (2nd ed.). Newbury Park: Sage.

Rhoades, L., \& Eisenberger, R. (2002). Perceived organizational support: A review of the literature. Journal of Applied Psychology, 87(4), 698

Rhoades, L., Eisenberger, R., \& Armeli, S. (2001). Affective commitment to the organization: The contribution of perceived organizational support. Journal of Applied Psychology, 86(5), 825-836.

Riggle, R. J., Edmondson, D. R., \& Hansen, J. D. (2009). A meta-analysis of the relationship between perceived organizational support and job outcomes: 20 years of research. Journal of Business Research, 62(10), 1027-1030.

Robbins, S. P., \& Judge, T. A. (2007). Organizational behavior (12th ed.). New Jersey: Pearson Prentice Hall.

Robbins, S. P., \& Judge, T. A. (2013). Organizational behavior. New Jersey: Pearson.

Saks, A. M. (2006). Antecedents and consequences of employee engagement. Journal of Managerial Psychology, 21(7), 600-619.

Scott, B. A., Colquitt, J. A., \& Zapata-Phelan, C. P. (2007). Justice as dependent variable: Subbordinate chrisma as a predictor of intenterpersonal and informational justice perceptions. Journal of Applied Psychology, 92(6), 1597-1609.

Scott, S. G., \& Bruce, R. A. (1994). Determinants of innovative behavior: A path model of individual innovation in the workplace. Academy of Management Journal, 37(3), 580-607.

Shiu, Y. M., \& Yu, T. W. (2010). Internal marketing, organisational culture, job satisfaction, and organisational performance in non-life insurance. The Service Industries Journal, 30(6), 793-809.

Simmons, A. L. (2011). The influence of openness to experience and organizational justice on creativity. Creativity Research Journal, 23(1), 9-23.

Simpson, M. R. (2009). Predictors of work engagement among medical-surgical registered nurses. Western Journal of Nursing Research, 31(1), 44-65.

Skarlicki, D. P., \& Latham, G. P. (2005). How can training be used to foster organizational justice? In J. Greenberg, \& J. A. Colquitt (Eds.), The handbook of organizational justice (pp. 3-56). N.J.: Erlbaum: Mahwah.

Sobel, M. E. (1982). Asymptotic confidence intervals for indirect effects in structural equation models. Sociological Methodology, 13(1982), 290-312.

Sze, C. C., \& Angeline, T. (2011). Engaging employees to their jobs: Role of exchange ideology as a moderator. African Journal of Business Management, 5(10), 3986-3994.

Talbot, R., Cooper, C., \& Barrow, S. (1992). Creativity and stress. Creativity and Innovation Management, 1(4), 183-193.

Taris, T. W., \& Schreurs, P. J. G. (2009). Well-being and organizational performance: An organizational-level test of the happy-productive worker hypothesis. Work \& Stress, 23(2), 120-136.

Tremblay, M., Cloutier, J., Simard, G., Chênevert, D., \& Vandenberghe, C. (2010). The role of HRM practices, procedural justice, organizational support and trust in organizational commitment and in-role and extra-role performance. The International Journal of Human Resource Management, 21(3), 405-433.

Ul-Haq, I., Ali, A., Umer-Azeen, M., Hijazi, S. T., Qurashi, T. M., \& Quyyum, A. (2010). Mediation of role employee engagement in creativity work process on the relationship of transformational leadership and employee creativity. European Journal of Economics, Finance and Administrative Sciences, 25, 94-101.

Vermeeren, B., Kuipers, B., \& Steijn, B. (2011). Two faces of the satisfaction mirror: A study of work environment, job satisfaction and customer satisfaction in Dutch municipalities. Review of Public Personnel Administration (in Press). 
Warr, P. B., \& Inceoglu, I. (2011). Job engagement, job satisfaction and contrasting associations with person-job fit. Journal of Occupational Health Psychology (in Press).

Wefald, A. J., \& Downey, R. G. (2009). Construct dimensionality of engagement and its relation with satisfaction. The Journal of Psychology, 143(1), 91-112.

Zapata-Phelan, C. P., Colquitt, J. A., Scott, B. A., \& Livingston, B. (2009). Procedural justice, interactional justice, and task performance: The mediating role of intrinsic motivation. Organizational Behavior and Human Decision Processes, 108(1), 93-105.

Zeldman, M. I. (1980). How management can develop and sustain a creative environment. Advanced Management Journal, 45, 23-27.

Zhang, X., \& Bartol, K. M. (2010). Linking empowering leadership and employee creativity: The influence of psychological empowerment, intrinsic motivation, and creative process engagement. Academy of Management Journal 53(1), 107-128.

Zhang, Y., Farh, J. L., \& Wang, H. (2011). Organizational antecedents of employee perceived organizational support in China: A grounded investigation. The International Journal of Human Resource Management, 23(2), 422-446. 